\title{
Ultrasonic measurement of blubber thickness in right whales
}

\author{
M.J. Moore* , C.A. Miller*, M.S. Morss*, R. Arthur*, W.A. Lange*, K.G. Prada ${ }^{*}$, M.K. MarX ${ }^{\dagger}$ And E.A. FreY ${ }^{*}$ \\ Contact e-mail: mmoore@whoi.edu
}

\begin{abstract}
The right whale population in the northwestern Atlantic appears to face the risk of extinction: ship and fishing gear trauma are significant mortality factors, but calving rates are also depressed compared to southern right whales. A major factor in calving success in many species is body condition. Knowledge of the dynamics of body condition is also important in studies of juvenile and sub-adult growth and seasonal changes in adults. This paper describes a method to assess body condition in live right whales. To characterise the acoustic properties of the blubber/muscle interface we first studied samples of Atlantic white-sided dolphin and right whale in the laboratory. Tissue heterogeneity was examined grossly and in histological sections. Acoustic echoes were strong from the sub-dermal connective tissue sheath(s). Echo strengths did not appear to vary with lipid content. We then used a $0.5 \mathrm{MHz}$ ultrasound transducer on a cantilevered $12 \mathrm{~m}$ pole to touch the back of surfacing right whales briefly. Multiple laboratory and field measurements on individual animals suggest repeated measures of blubber thickness at a single location are reasonably consistent. Data will be normalised to both sampling position on the body and to length of the animal, estimated by mensuration from stereo video images of the animal during sampling. In this way, using a long-term consistent database of blubber thickness measurements, and catalogued reproductive histories from on-going photographic identification studies, we plan to assess the significance of changing body condition in right whale population dynamics.
\end{abstract}

KEYWORDS: NORTH ATLANTIC RIGHT WHALE; NUTRITION; REPRODUCTION; ULTRASOUND TECHNIQUES

\section{INTRODUCTION}

The North Atlantic right whale (Eubalaena glacialis) was estimated to have numbered 12,000-15,000 individuals in 1530 in the northwestern Atlantic (Gaskin, 1991). In spite of the absence of significant reported whaling mortality in the past 150 years, the total population today is only 300 individuals, of which about half are sexually mature (IWC, $2001)$. In the early 1990 s, the population growth rate was estimated at $2.5 \%$ per annum (Knowlton et al., 1994), although a more recent analysis suggests that the population is now decreasing (Caswell et al., 1999).

By contrast, the south Atlantic populations of the southern right whale (Eubalaena australis) have increase rates of 7.3\% (Best and Underhill, 1998) and 7.5\% (Payne et al., 1990), respectively. Table 1 comprises the status of the northwestern and southeastern Atlantic populations. Two major mortality factors in the northwestern Atlantic are known to be ship strikes and gear entanglement. Evidence of both is commonly seen in scars on survivors and carcasses following these events (IWC, 2001). However, this mortality is not sufficient to explain that the reproductive rate in the North Atlantic is only about half of that in the South Atlantic. Only $38 \%$ of the mature females are known to be reproductively successful in the NW Atlantic population (Brown et al., 1994). Therefore there must also be a failure in calf production in addition to shipping and entanglement deaths. Calving rate is influenced by the ability to conceive and to carry foetuses to birth. Both these parameters could be affected by a number of factors including inbreeding, disease, toxic chemical exposure and inadequate nutrition associated with prey availability and other complex habitat quality interactions (IWC, 2001). In rodents and humans, fertility is impacted by an insufficiency or an excess of body fat (Marshall and Hammond, 1926; Frisch, 1984; Thomas, 1990).

In order to test the hypothesis that body condition is predictive of reproductive success, or investigate other relationships between body condition and population dynamics, a reliable non-destructive method for measuring body condition in right whales is required. Ultrasound has been used in the past to measure blubber thickness in restrained marine mammals (Gales and Burton, 1987). The approach is based upon the knowledge that tissue heterogeneity can cause attenuation and reflection of sound waves (Bamber and Hill, 1979; Gammell et al., 1979; McClements and Povey, 1992). Tissue interfaces, such as between fat and connective tissue show strong reflectivity. Sound also attenuates to a greater extent with higher lipid content (Gammell et al., 1979). In this study we first established the acoustic properties of a series of Atlantic white-sided dolphin (Lagenorhynchus acutus) blubber samples and a single North Atlantic right whale sample in the laboratory, and then applied this knowledge to North Atlantic right whales at sea.

\section{Table 1}

Summary of population status for northwest and southeast Atlantic right whales.

\begin{tabular}{lcc}
\hline & $\begin{array}{c}\text { Northwest Atlantic } \\
\text { (Caswell et al. 1999, } \\
\text { Kraus et al., 2001) }\end{array}$ & Southeast Atlantic \\
\hline $\begin{array}{l}\text { Population growth } \\
\text { rate (\%) }\end{array}$ & Negative to 2.5 & $\begin{array}{c}7.3(1979-96) \\
\text { Reproductive rate (\%) }\end{array}$ \\
$\begin{array}{lcc}\text { Calving interval (y) } \\
\text { Mortality rate }\end{array}$ & $\begin{array}{c}\text { (Becent increase to }>5) \\
2.0 \%\end{array}$ & $\begin{array}{c}\text { Unknown } \\
\text { (Best } \text { et al., 2001) } \\
\text { Low }\end{array}$ \\
\hline
\end{tabular}

\section{METHODS}

\section{Ultrasound}

An acoustic system ${ }^{1}$ was used that has been applied to a diverse range of non-destructive thickness testing in steel, power generation and livestock industries. It has a broad ${ }^{1}$ Epoch, 111 Model 2300, Panametrics Inc., 221 Crescent St, Waltham MA 02154, USA.

\footnotetext{
* Woods Hole Oceanographic Institution, Woods Hole, MA 02543, USA.

+ Upper Cape Systems, 29 Prince Henry Drive, Falmouth, MA 02536, USA.

† New England Aquarium, Central Wharf, Boston MA 02110, USA.

* Boston College, Chesnut Hill, MA 02167-9191, USA.
} 
range of adjustable parameters: pulse strength can be set at 100, 200 and 400V; the receiving gain can be adjusted from 0-100dB; damping can be set at 50, 150 and 400 ohms; and filtration can be standard or high pass. The display on the unit shows an $\mathrm{x}-\mathrm{y}$ plot of wave-form pattern, with depth (timebase) range being calculated from selected transmission velocity, with adjustable zero offset. The system samples at a rate of $30 \mathrm{~Hz}$. The wave-form can be full, half and unrectified. Other parameters are also adjustable, but are less relevant to the application described here. The unit has a bi-directional serial port. A wide range of transducers is available, with the lowest frequency transducer being $0.5 \mathrm{MHz}$. The instrument can be powered with an external $12 \mathrm{~V}$ supply, or can be supplied with internal 6 or $12 \mathrm{~V}$ lead acid batteries. In this study, three transducers were used: $0.5,1.0$ and $2.2 \mathrm{MHz}$ (Panametrics Catalog Nos A301S, A303S, and A304S respectively).

\section{Data acquisition and analysis}

Real time data recording for this unit was developed as a custom PC software package by Upper Cape Systems ${ }^{2}$. The recording program uses a serial communications link with the Epoch 111 ultrasound system. It sends commands and receives responses and data through the COM1 or COM2 port. It gives interactive control of parameters such as gain, velocity and time-base, real time capture, display and recording of wave-forms at $2 \mathrm{~Hz}$, recording directory selection and time-stamped records. Acoustic parameters in use during the recording are also displayed. Data are automatically stored in sub-directories labelled by Julian day. Initiation of a recording session opens a new file, which closes on the stop command. Files are labelled by start time. Each data frame is labelled with date and time of data acquisition. This software is used with a $200 \mathrm{MHz}$ laptop with 2GB hard-drive, and internal zip drive for data backup, using Microsoft Windows NT 4.0 as the operating system. Files are manually backed-up to an internal 100MB zip drive after each recording period. Data playback was also developed by Upper Cape Systems. This program allows selection of files, and playback of filed records as single frame, or at an adjustable continuous rate. Specific time points in the file can be selected.

\section{Laboratory studies}

\section{White-sided dolphin}

Samples of skin, blubber and superficial muscle were collected from ten white-sided dolphins, which were excised after a mass stranding on Cape Cod in January 1998. The 5 $\times 5 \times 5 \mathrm{~cm}$ samples were taken lateral to the dorsal fin and frozen at $-10^{\circ} \mathrm{C}$ until thawed for analysis. The time elapsed from death to sampling ranged from 6 to 24 hours. Sub-samples were fixed in $10 \%$ buffered formalin, embedded in paraffin, sectioned at $5 \mu \mathrm{m}$ and stained with haematoxylin and eosin and Masson's trichrome (Luna, 1968). Sections were examined histologically. Lipid was extracted from thawed blubber samples according to the method of Folch (1957) as modified by Iverson (1988) and Smith et al. (1997).

\section{North Atlantic right whale}

A $5 \times 5 \times 15 \mathrm{~cm}$ core of skin, blubber and muscle from a North Atlantic right whale (No. 2220), necropsied at Wellfleet MA on 9 March 1996, was stored frozen at $-20^{\circ} \mathrm{C}$. For ultrasound testing, the sample was thawed and suspended inside a plastic bag in a water bath at $37^{\circ} \mathrm{C}$. A $3 \mathrm{~cm}$

229 Prince Henry Drive, Falmouth MA 02536, USA. collar of styrofoam surrounded the core, such that the upper $3 \mathrm{~cm}$ of the core was above the water level. The skin surface was covered with ice. In this way the thermal gradient, and hence oil phase, presumed to exist in vivo between the body and ambient sea water was approximately simulated.

\section{Transducer deployment systems at sea with right whales}

The transducer was hinged on the end of one of two pole systems: (1) a hand-held carbon fibre pole $5.4 \mathrm{~m}$ in length, $2 \mathrm{~cm}$ in diameter, with a wall thickness of $3 \mathrm{~mm}^{3}$; (2) a cantilevered pole system (Fig. 1). For the latter, two $6.5 \mathrm{~m}$ carbon fibre sailboat spars ${ }^{4}$ were sleeved into one another with a $1 \mathrm{~m}$ overlap, to achieve a total length of $12 \mathrm{~m}$. The inner pole was a $5.8 \mathrm{~kg}$ cylinder of $64 \mathrm{~mm}$ outside diameter with a $2.5 \mathrm{~mm}$ wall thickness. The outer pole was a $6.8 \mathrm{~kg}$ tapered spar, with an outer diameter where it sleeves into the inner pole of $59 \mathrm{~mm}$, decreasing to $35 \mathrm{~mm}$ at the outer tip. Wall thickness averaged $2 \mathrm{~mm}$. The two sections of the pole were disassembled for travel to the study area. The $12 \mathrm{~m}$ pole slides in and out through a pivot point consisting of a plastic block with a hole bored to accommodate the pole. This pivot can swivel up and down as well as rotate, allowing full control of the pole tip by movement of the inboard pole end. The pivot was mounted on a bowsprit set at 45 degrees to port of the midline of the boat. The inboard end of the pole carried an $11.9 \mathrm{~kg}$ solid stainless steel handle, which also acted as a counterweight. The ultrasound transducer on the outer pole end was rigidly flush-mounted in a $7 \mathrm{~mm}$ thick, $22 \mathrm{~cm}$ diameter clear plastic (Lexan) disc. The disc was hinged on the pole end with the axis of the hinge being perpendicular to the long axis of the pole and parallel to the water. Thus, as the disc was laid on the whale's back, the transducer settled flat on the animal, irrespective of pole angle. The operator rotated the pole axis to ensure a flat landing laterally. The coaxial cable from the transducer was inserted down the length of the pole. The length of this cable had to exceed twice the length of the pole to allow retraction of the pole, whilst maintaining connection with the recording unit under the foredeck. This permitted disinfection of the probe with alcohol and a sterile swab and application of ultrasound gel between animals. Stereo video cameras were mounted on a $2 \mathrm{~m}$ mast on the pivot point to allow time-coded video recording of the probing event to facilitate interpretation of ultrasound recordings and subsequent mensuration of the image to estimate body length. Details of these methods will be reported elsewhere. In this study, the position of the transducer on the back of the animal is reported as an estimate of the probe position in terms of a percentage of the distance from the blowhole to the fluke notch after review of available video tape frames.

\section{Platform}

The vessel for this operation had the following features: a rigid foredeck, suitable for mounting the bowsprit; an open well aft of the foredeck allowing the pole operator to swing the pole end as needed; an upper steering and observation deck; and adequate stability to support the weight of the pole when deployed laterally. The vessel was a $7.5 \mathrm{~m}$, deep-vee centre console hull ${ }^{5}$ with a $330 \mathrm{HP}$ Mercruiser inboard outboard. A crew of four was deployed as follows: the pole operator; a 35mm still photographer for photo-ID images; an

\footnotetext{
${ }^{3}$ Fiberspar, 2380 Cranberry Highway, Wareham MA, USA.

${ }^{4}$ Composite Engineering, Baker Ave, Concord MA, USA.

${ }^{5}$ Surfhunter, Atlantic Boats, 2820 Cranberry Highway, Wareham MA, USA.
} 


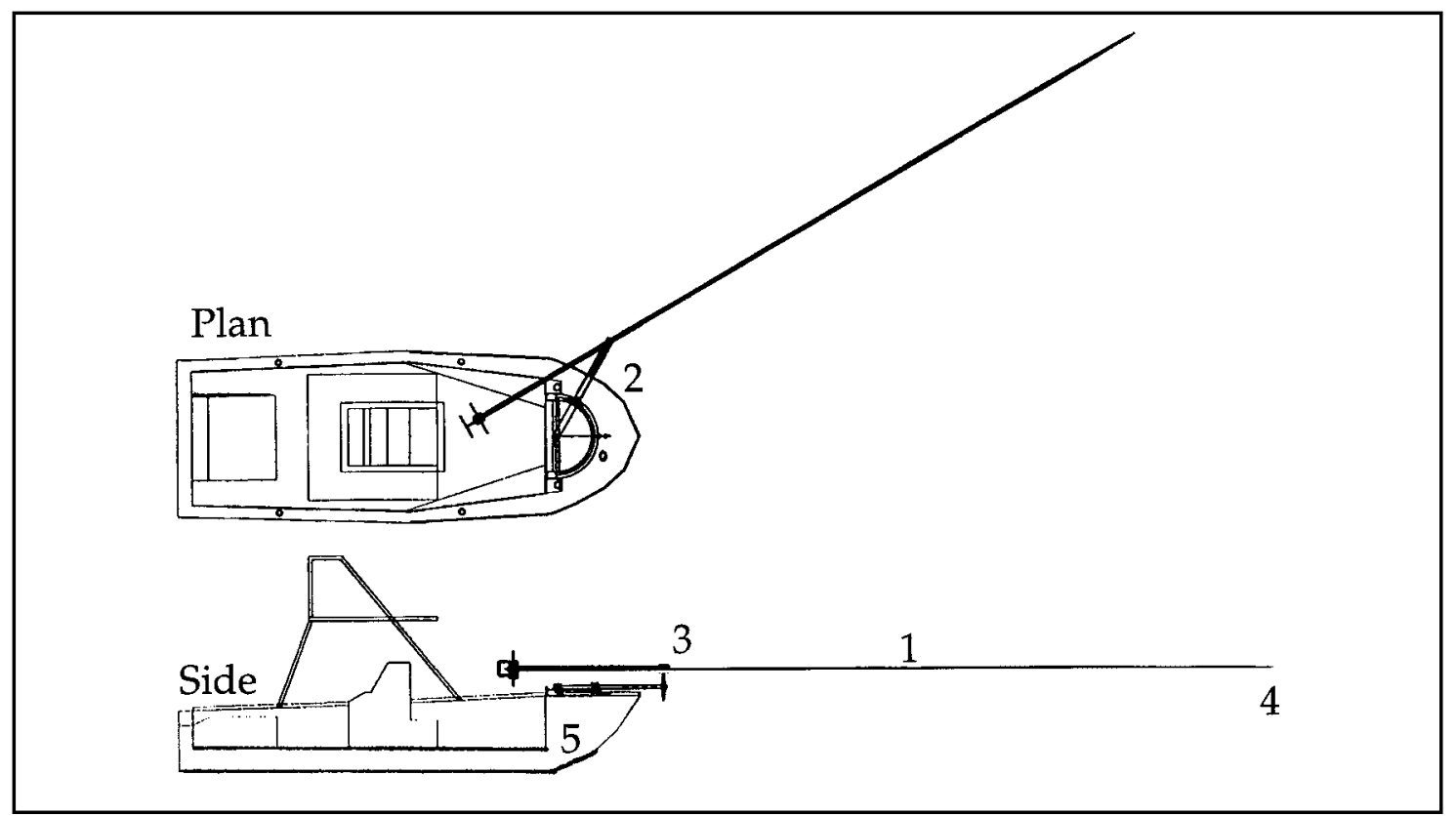

Fig. 1. Apparatus used to lay the ultrasound probe flat on the back of a right whale. Pole (1) is cantilevered off a laterally mounted bowsprit (2). The pole slides in and out, and rotates, through a vertically adjustable pivot (3) that is mounted on the bowsprit tip. The pole operator stands in front of the steering console, swinging the pole tip to meet the whale. The ultrasound transducer head, embedded in a $22 \mathrm{~cm}$ diameter Lexan landing disc, is hinged on the pole tip (4). The data cable runs down the inside of the pole to a data recording system housed in a waterproof Pelican case stowed under the foredeck (5). A pair of stereo video cameras are mounted on the pivot (3) to record the location of the probe on the animal, and allow body length estimation.

observer to sketch callosity patterns, to take additional $35 \mathrm{~mm}$ photographs and observe whale movement dynamics; and the helmsman.

\section{Photo ID}

Routine $35 \mathrm{~mm}$ photographs of each animal were taken, optimally of left and right head, dorsal and ventral flukes and other markings. Photographs were then compared with the North West Atlantic right whale catalogue at the New England Aquarium to ascertain catalogue number and reproductive history of animals studied.

\section{RESULTS}

\section{Laboratory analysis}

Histological analysis of the white-sided dolphin tissues showed two connective tissue layers previously described (Pabst, 1990) collectively as the subdermal connective tissue sheath (SDS) between the blubber and muscle layers. The second connective tissue layer interdigitated with the muscle tissue (Fig. 2). Smaller bands were observed between the two major layers. The second layer was more uniform and substantial than the first. Masson Trichrome staining showed the connective tissue sheaths to consist primarily of collagen. The available parameters on the Epoch system were empirically adjusted to maximise the echo strength at the subdermal connective sheath layers. This resulted in the use of a pulse strength of $400 \mathrm{~V}$, a receiving gain of $60 \mathrm{~dB}$, damping at $400 \mathrm{ohms}$ and high pass filtration. Acoustically the epidermis/dermis junction, and the two major layers of subdermal connective sheath gave strong peaks at all the frequencies used (Fig. 3). The distance (mean \pm SD in $\mathrm{mm}$ ) measured between skin surface and lower subdermal sheath was $24.1 \pm 0.2$ measured with a ruler on the cut edge, $v s$ $24.8 \pm 0.2$ measured acoustically in samples from eight different animals. It was observed that small changes in transducer orientation resulted in variable peak heights, but not position. Lipid content (mean $\%$ wet weight $\pm \mathrm{SD}$ ) was
59.0 77.3. Echo strength in the blubber layer did not appear to vary with lipid content. A series of studies (data not shown), using $0.5,1.0$ and $2.25 \mathrm{MHz}$ transducers, were run to compare echo strength, sound attenuation and transmission velocity with lipid content. No relationships were apparent.

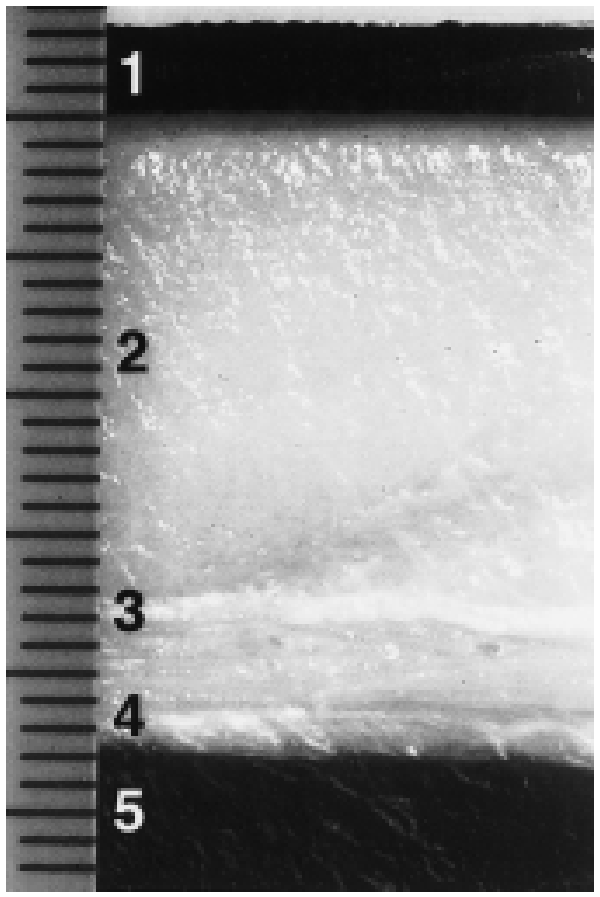

Fig. 2. Photograph of a slice of white-sided dolphin skin (1), blubber (2), upper (3) and lower (4) subdermal connective sheaths, and muscle (5). Scale marker: small division $=1 \mathrm{~mm}$.

The right whale skin, blubber and muscle core described above was examined visually and with the Panametrics system (Fig. 4). Fig. 4A shows a photograph of the slice 

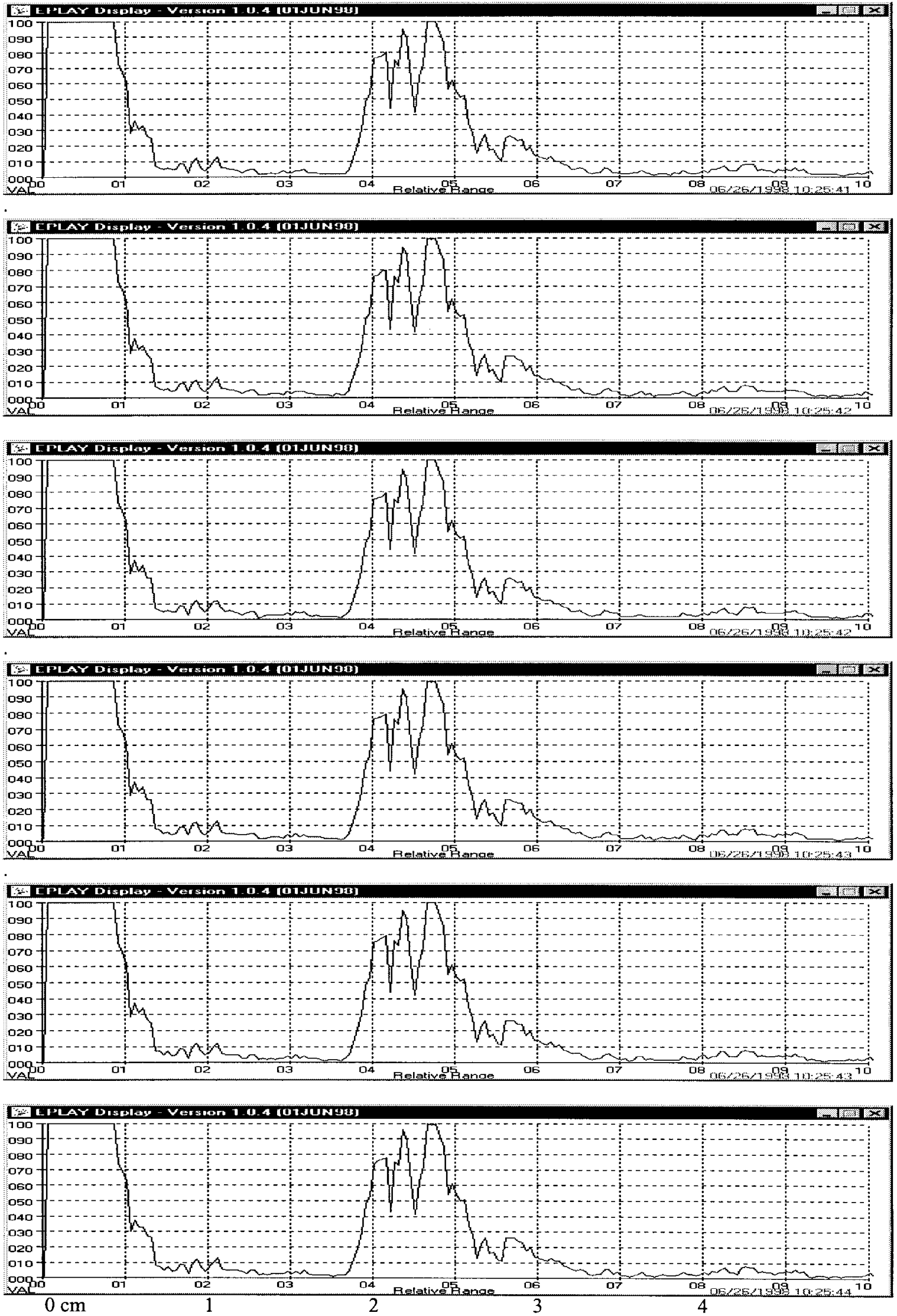

Fig. 3. A series of echoes from a single location on a sample of white-sided dolphin blubber and muscle. 1.0MHz. Vertical bars at $5 \mathrm{~mm}$ spacing, assuming a velocity of $1,770 \mathrm{~ms}^{-1}$

examined. The lower, more vascularised portion of blubber, (pink in life, grey in the image) overlay an upper and lower connective tissue sheath, which in turn overlay the skeletal muscle. In preliminary trials (data not shown) it was established that the optimum transducer frequency for this blubber thickness for the Epoch system was $0.5 \mathrm{MHz}$. This choice was made on peak strength, and reproducibility. Fig. $4 \mathrm{~B}$ shows a representative trace of this slice. Strong peaks were observed at both sheath layers $(9.7$ and $11.2 \mathrm{~cm}$ respectively). The system was calibrated to assume 1,770 $\mathrm{ms}^{-1}$ transmission velocity. This was used as it gave an accurate acoustic measurement of what was measured 


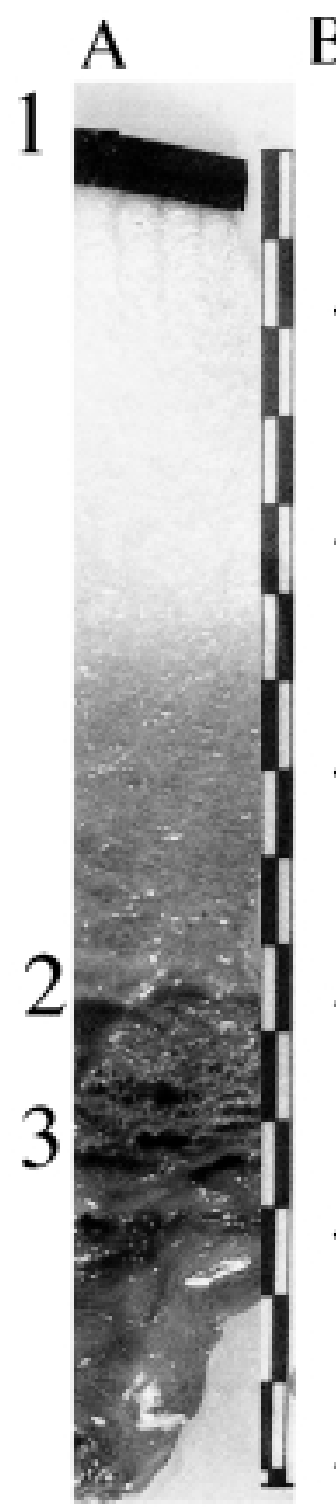

B

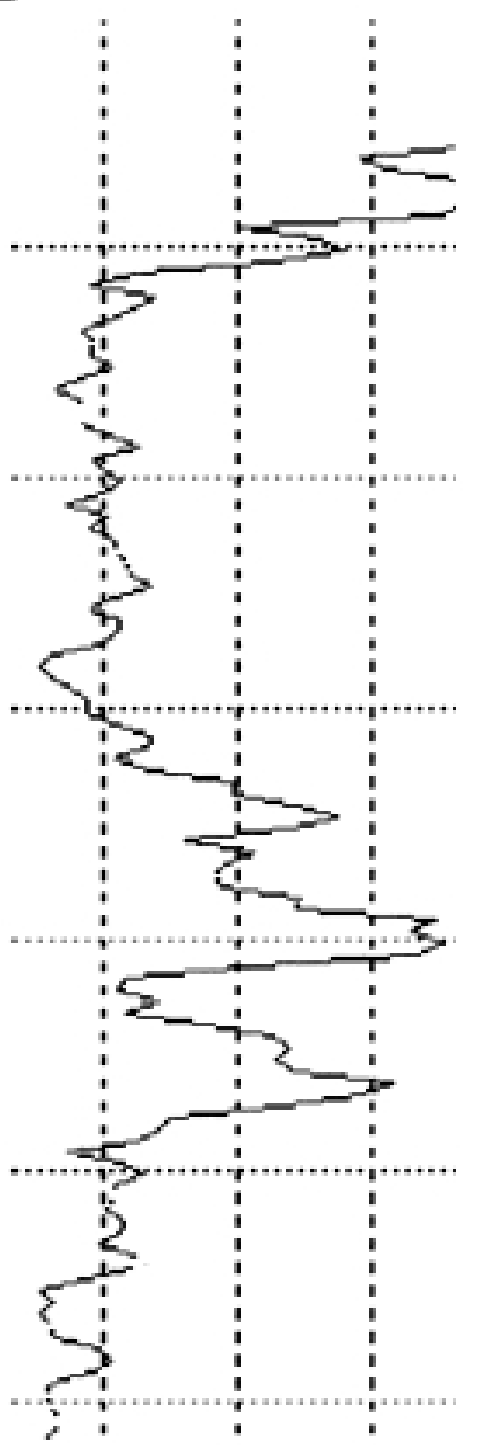

Fig. 4 A: Photograph of a cross-section of blubber and muscle from a North Atlantic right whale, catalogue No. 2220, from the necropsy at Wellfleet MA, March 9 1996. (1) Epidermis. (2) Superficial subdermal connective tissue sheath. (3) Deep subdermal connective tissue sheath. B: $0.5 \mathrm{MHz}$ echograph of the same sample. Strong signal strength is evident at both (2) and (3). Centimetre scale in centre.

physically for the two sheath layers $(9.5$ and $11.1 \mathrm{~cm}$ respectively). Similar transmission velocities are reported for other oils (McIntire, 1991).

\section{Field deployment}

Results with the $5.4 \mathrm{~m}$ hand-held pole were occasionally excellent, but in general the pole proved to be too short to allow successful approaches. The $12 \mathrm{~m}$ cantilevered pole was first deployed with multiple outriggers and guy wires. It proved to be unwieldy and hard to operate. In August 1997, the $12 \mathrm{~m}$ pole was again deployed in the Bay of Fundy, Canada, but without outriggers or guy wires (Fig. 1). The loss of rigidity was more than compensated for by the enhanced manoeuverability. The resultant approaches and 'touches' with an ultrasound probe are listed in Table 2. At this time the Panametrics system had not been acquired. Ultrasound data, from another system used for that field period are not shown here as the system then in use proved to yield poor quality data. An 'approach' was defined as an encounter within 30 feet of the surfaced whale and moving with it. The best approaches occurred in dense concentrations of whales: 10-20 whales or more surfacing or logging at less than half a mile apart. Usually the closest animal just surfacing from a long dive or logging at the surface was chosen for an approach. The most productive approaches were those when the vessel slowly idled, without changing engine speed, towards the animal in a sector 90-135 degrees from the anterior/posterior axis of the animal moving in the same direction as the animal (Fig. 5).

Table 2

Summary of field events during approaches of northern right whales for blubber thickness measurements in the Bay of Fundy.

\begin{tabular}{ccccccc}
\hline $\begin{array}{c}\text { Date } \\
\text { (Aug. } \\
1997)\end{array}$ & $\begin{array}{c}\text { Sea } \\
\text { state }\end{array}$ & $\begin{array}{c}\text { Visibility } \\
\text { (n.miles) }\end{array}$ & $\begin{array}{c}\text { No. } \\
\text { Id'd }\end{array}$ & $\begin{array}{c}\text { No. } \\
\text { approaches }\end{array}$ & $\begin{array}{c}\text { No. } \\
\text { touched }\end{array}$ & $\begin{array}{c}\text { No. probe } \\
\text { touches }\end{array}$ \\
\hline 3 & 0 & $2-4$ & 33 & 29 & 17 & 19 \\
4 & 2 & $10-15$ & 54 & 38 & 11 & 15 \\
6 & $0-3$ & 15 & 52 & 32 & 22 & 26 \\
8 & $1-3$ & $2-10$ & 33 & 19 & 14 & 15 \\
10 & $1-2$ & $10-15$ & 44 & 30 & 26 & 39 \\
13 & $0-1$ & 15 & 51 & 38 & 31 & 46 \\
Totals & & & 267 & 186 & 121 & 160 \\
\hline
\end{tabular}

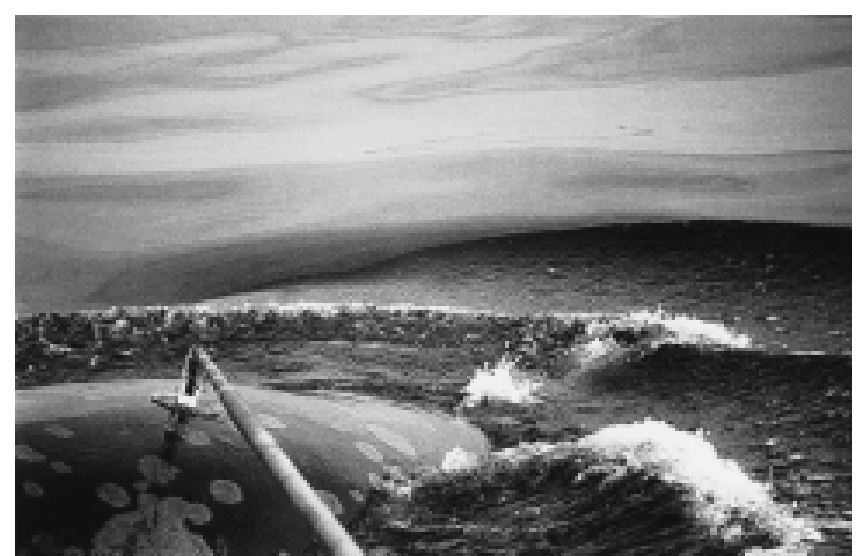

Fig. 5 The optimum orientation for approaching surfacing right whale to apply an ultrasound probe. The vessel is behind and to the side of the surfacing whale. The image shows the pole end with the transducer laying on the back of a northern right whale just after the blowholes have submerged at right.

The Epoch 111 system was first deployed in the field in February 1998 in Cape Cod Bay, MA, USA. In this habitat whales are generally hard to approach and are scarce. One animal was approached three times during an afternoon. The results are shown in Fig. 6. Fig. 7 shows a selection of traces over a 7 second interval from a second individual. Data are summarised in Table 3 (p. 308). The major peaks at $18-23 \mathrm{~cm}$ in depth represent echoes from the usually bilaminar subdermal connective tissue sheath. A larger dataset from ongoing deployments of this system will be reported elsewhere.

\section{DISCUSSION}

This paper reports a functional system to measure blubber thickness at sea in right whales, after obtaining laboratory data from blubber/muscle samples from nine white-sided 


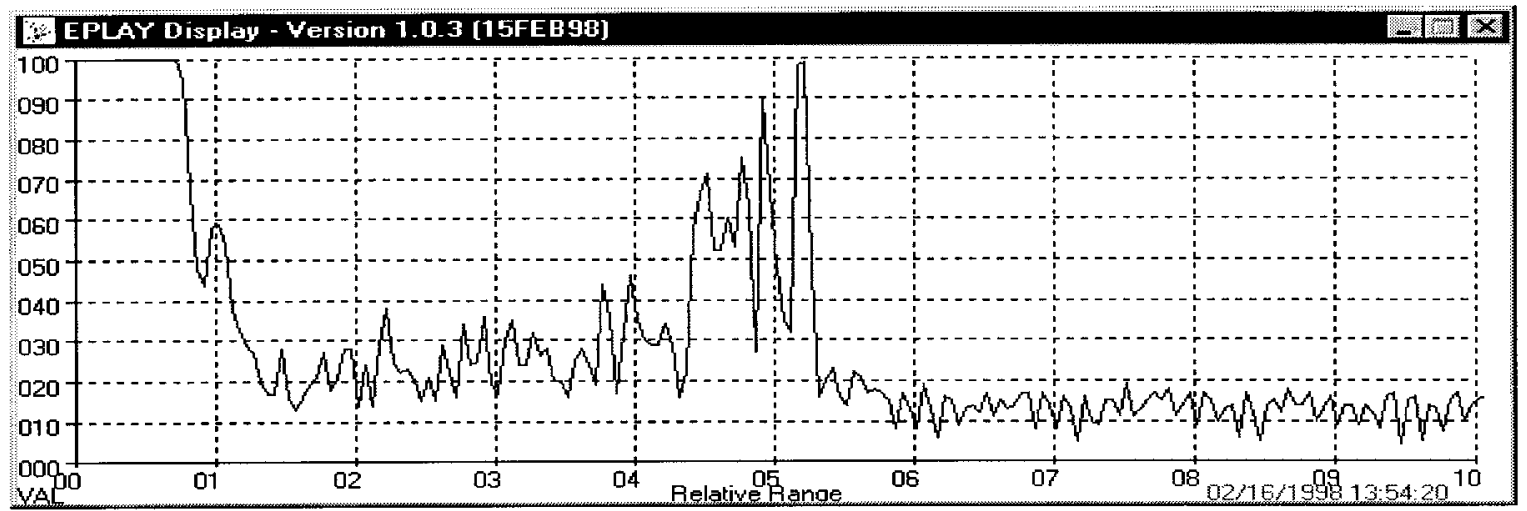

$\mathrm{A}$

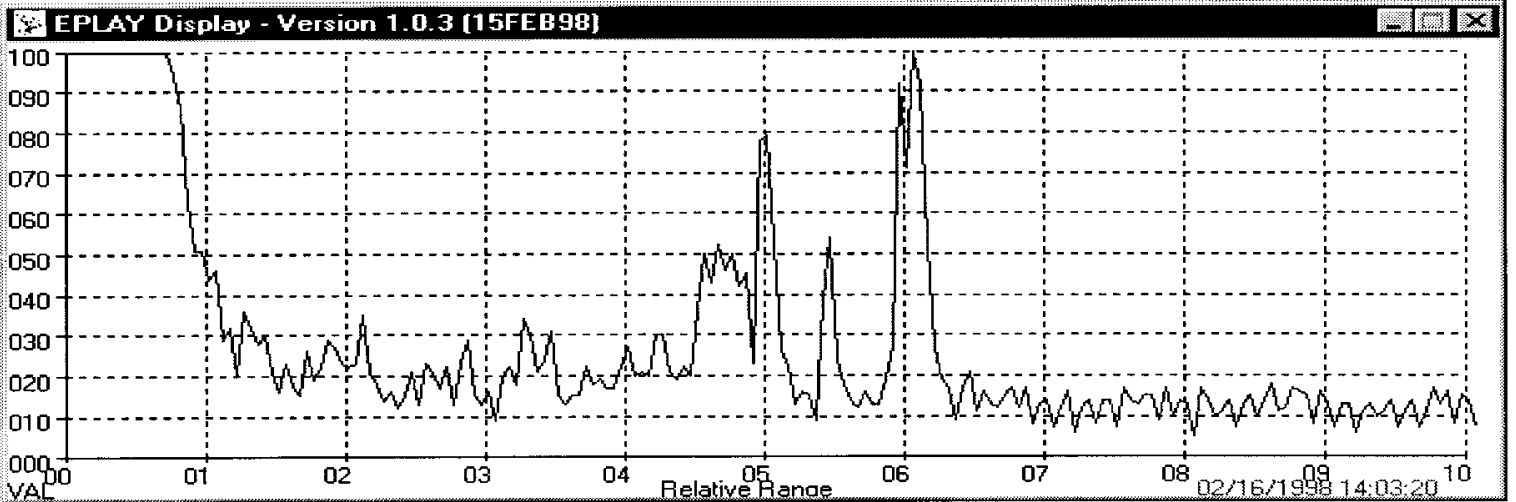

$\mathrm{B}$

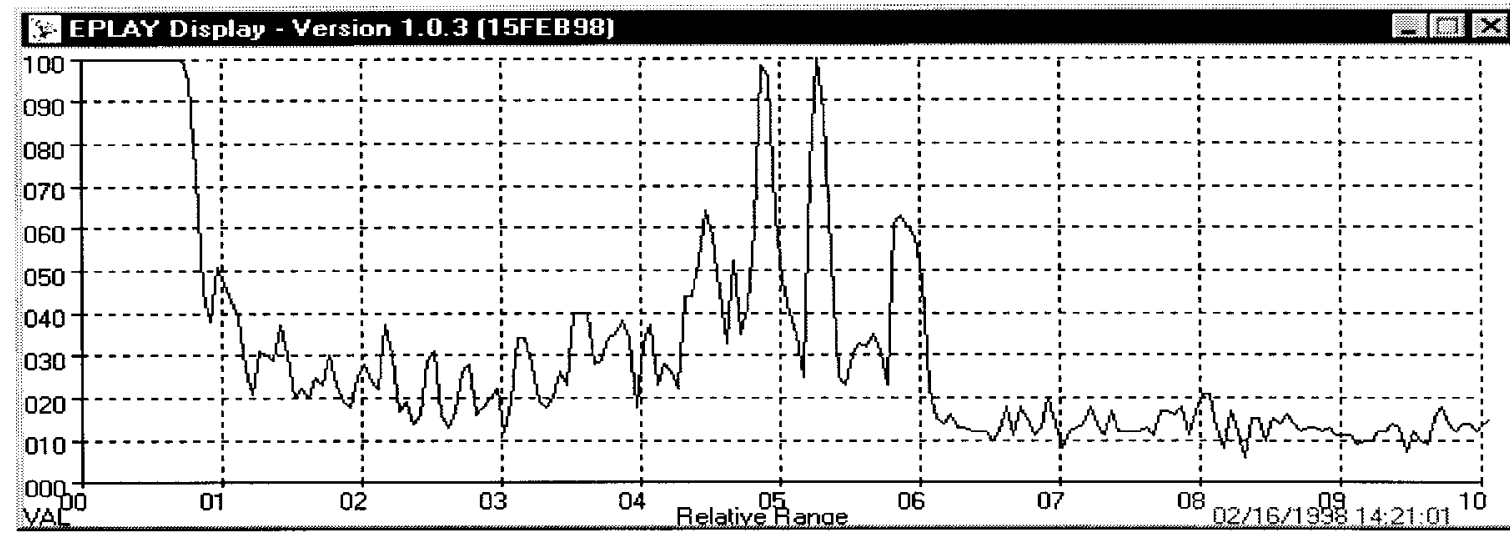

$\mathrm{C}$

\section{$\begin{array}{llllllllll}0 \mathrm{~cm} & 4 & 8 & 12 & 16 & 20 & 24 & 28 & 32 & 36\end{array}$}

3640

Fig. 6. Ultrasonographs through dorsal skin and blubber from a single North Atlantic right whale, (Field ID 'F'), during three separate approaches on 16 February 1998. For each, approach time (hh.min.sec) and position (deg. min. latitude N, longitude W) are given: A: $13: 54: 20,41^{\circ} 51.870^{\circ}$ 10.4, B: 14:03:20, $41^{\circ} 51.670^{\circ} 10.7, \mathrm{C}: 14: 21: 01,41^{\circ} 51.9,70^{\circ} 10.8$. Vertical bars at $40 \mathrm{~mm}$ spacing, assuming a velocity of $1,770 \mathrm{~ms}{ }^{-1}$. $0.5 \mathrm{MHz}$ transducer frequency. Strong peaks from the upper and lower subdermal connective tissue sheaths are evident at $18-20 \mathrm{~cm}$ and $21-24 \mathrm{~cm}$ respectively.

dolphins and one right whale. The data suggest that such measurements accurately reflect echoes from the bilaminar subdermal connective tissue sheath found at the blubbermuscle interface in both species. The minor difference $(0.7 \mathrm{~mm}$ on average) in measurement compared with the ruler and acoustic measures in the white-sided dolphins occurred within the accuracy one could expect to obtain with a ruler.

Equally, one cannot expect an acoustic accuracy greater than $3.5 \mathrm{~mm}$ at the sound velocity in use $\left(1,770 \mathrm{~ms}^{-1}\right)$. The repeatability of these measurements in the field in right whales was in part confirmed by the data shown in Fig. 6 .
Before these echograms can be used objectively to measure blubber thickness in the field, a statistical approach to waveform analysis will have to be developed. Such data will then have to be analysed in the context of acoustic maps of the dorsal region of right whales obtained either at necropsy, or from entangled animals prior to release. Such analysis will then test the validity of one or a few point measures in predicting general body condition in individual animals. The value of the eventual approach for testing the hypothesis that blubber thickness dynamics predict reproductive success can only be assessed once a substantially larger, multi-year dataset is in hand and appropriately analysed. In the final 


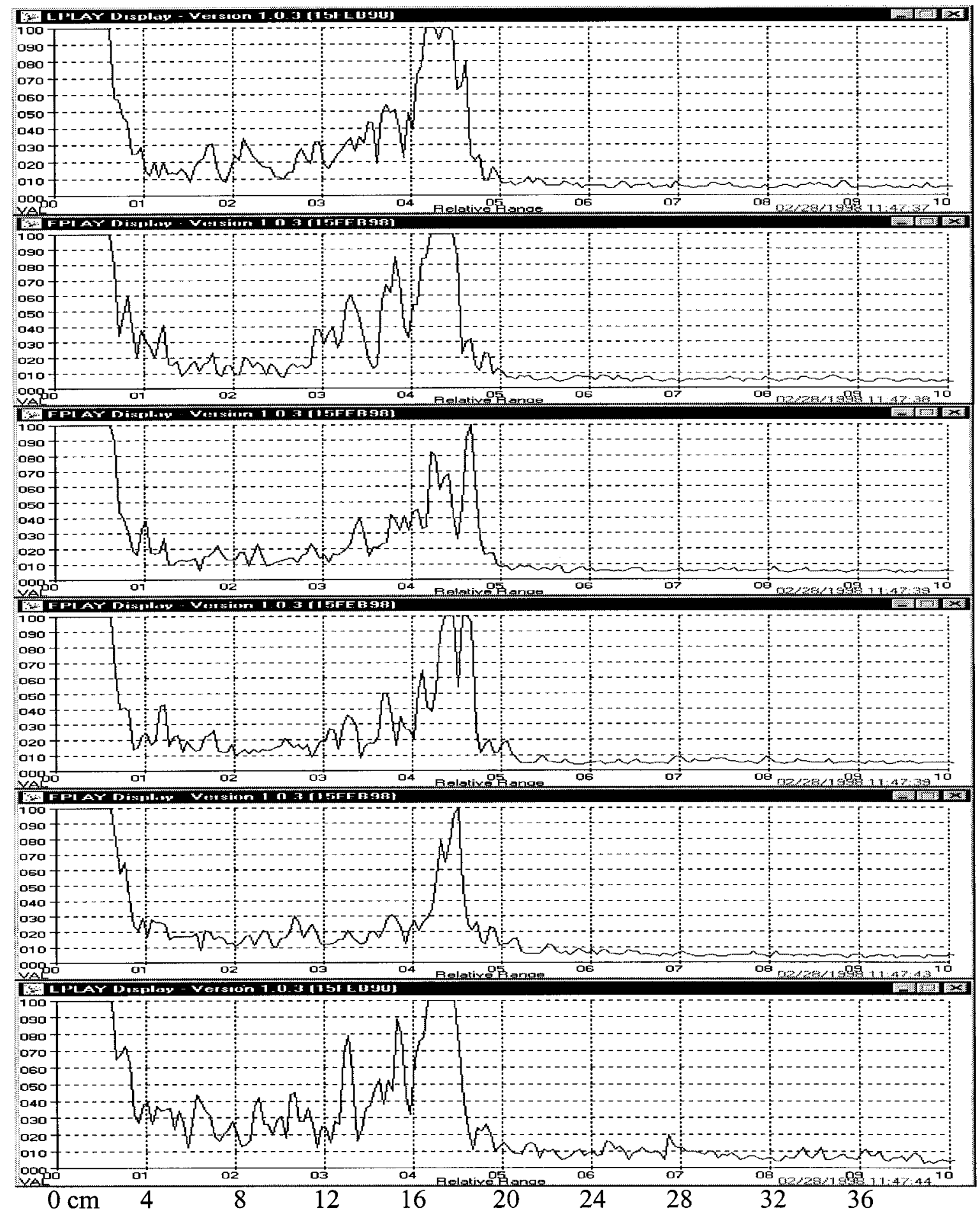

Fig. 7. Ultrasonographs obtained during a seven second period from a single North Atlantic right whale, Field ID 'F', 28 February 1998, Cape Cod Bay, MA, USA. Frequency $=0.5 \mathrm{MHz}$, Gain $=60 \mathrm{~dB}$. Vertical bars spaced at $40 \mathrm{~mm}$ assuming a velocity of $1,770 \mathrm{~ms}^{-1}$. $0.5 \mathrm{MHz}$ transducer frequency. Subdermal connective tissue sheath peaks are evident at $17-19 \mathrm{~cm}$ depth.

section we discuss relevant literature, the problems apparent with the approach described here, and the manipulations these and future data will have to be subjected to before the necessary comparisons can be made.

In fin and sei whales it has been found that the dorsal posterior part of the body is a major site for lipid storage in both blubber and muscle (Lockyer et al., 1985). These authors suggested that this part of the body was the best area for condition estimates, and that body girth should be estimated at the mid-point of the body. A related study showed that increased body fatness correlated with increased food abundance and fecundity (Lockyer et al., 1985).
Blubber thickness data in right whale literature is sparse (Thompson, 1928; Matthews, 1938; Omura et al., 1969). Unpublished data are also available for necropsied animals sampled from the USA in the past 10 years (Kraus et al., pers. comm. and unpublished data). These data will be used to build a numerical model of the dorsal blubber coat layer of northern right whales. This model will allow the standardisation of the data described here in terms of the position on the animal at which the measurement was made, on the basis of the video record. This same video record will also allow normalisation of the data in terms of body length, using available techniques for body length estimation from 
Table 3

Measurements of blubber thickness from individually identified North Atlantic right whales in Cape Cod Bay in February 1998.

\begin{tabular}{ccccc}
\hline $\begin{array}{c}\text { Date } \\
\text { (Feb. } \\
1998)\end{array}$ & $\begin{array}{c}\text { Catalogue } \\
\text { no. }\end{array}$ & $\begin{array}{c}\text { Thickness } \\
(\mathrm{cm})\end{array}$ & $\begin{array}{c}\text { Estimated position of } \\
\text { touch (\% distance from } \\
\text { blowhole to fluke notch) }\end{array}$ & $\begin{array}{c}\text { No. } \\
\text { echographs }\end{array}$ \\
\hline 10 & 1407 & 19 & 34 & 1 \\
16 & 1503 & 12 & 31 & 3 \\
16 & 1039 & 22 & 34 & 2 \\
16 & 1039 & 20 & 34 & 4 \\
16 & 1039 & 23 & 44 & 3 \\
16 & 1039 & 19 & 25 & 4 \\
20 & 2614 & 14 & 28 & 4 \\
20 & 2614 & 18 & 44 & 4 \\
28 & 1709 & 17 & 44 & 3 \\
28 & 1709 & 16 & 31 & 4 \\
\hline
\end{tabular}

head images (Whitehead and Payne, 1981). Once a standardised condition index has been established it will then be possible to investigate the relationship between condition and reproductive success for the individual animals recognised photographically.

Limitations to data quantity and quality reflect field and technical variables. The system has been deployed in two locations. In Cape Cod Bay, the animals are in water depths of $40 \mathrm{~m}$ or less and are often sub-surface skim feeding. The duration of surface intervals are short and the number of breaths per surfacing few. They appear to need little recuperation before the next dive. In contrast, animals in the Bay of Fundy are in depths of $200 \mathrm{~m}$, often bottom feeding as evidenced by mud on their heads and have prolonged multiple breath surfacings where they are often resting at the surface. Right whale behaviour in the latter habitat is much more conducive to successful deployment of the system described. Current effort is thus focusing on the Bay of Fundy to generate a dataset with multiple measures of blubber thickness from individual animals. The aim is to develop a set of data that will rank individuals for body condition and compare those with the reproductive success of the same individuals.

Technical limitations in this study included both acoustic and data processing. One issue concerns the variability of quality in acoustic coupling achieved when contact is actually made. This variable affects echo strength but not time of return. Therefore, as long as the characteristic sharp tall peak of the lower subdermal sheath is detectable, we believe that the data quality is acceptable. Data processing limitations of the system reflect primarily the sampling rate of the serial port link to the laptop. This could be augmented if the necessary hardware and software developments for parallel port data retrieval were instituted.

Data interpretation may be complicated by the physical and chemical properties of blubber. If blubber is not sufficiently elastic to contract as muscle mass and hence sub-blubber body circumference decreases, it is possible that a leaner muscle mass may actually lead to an increased blubber thickness. Properties of blubber in this regard need to be experimentally evaluated. Studies of captive animals would be of value. Furthermore, changes in the lipid and/or collagen content of blubber could change the echo characteristics. Comparison of the lipid content and blubber echo strength in the dolphin samples did not show any change in echo strength with lipid content. This may reflect the small range in lipid content in the samples available. It may also suggest, in dolphin blubber at least, that lipid content affects echo strength and position less than structural interfaces. Finally, a comparison of the acoustic properties of blubber in live $v s$ dead animals must be made.
In summary, the method described here may have genuine utility in addressing the question of the role of body condition in right whale fecundity. That utility will depend on the ability to employ this tool consistently and persistently over the next 4-6 years, with appropriate objective data analysis. An additional benefit of this development is the necessary engineering and fabrication of a pole system that can contact the backs of right whales in an unobtrusive manner for any appropriate purpose.

\section{ACKNOWLEDGEMENTS}

Funding for this project was provided by the Massachusetts Environmental Trust, the Rinehart Coastal Research Center and the Office of Naval Research (N00014-98-1-0849). Field work conducted under NMFS Permit to Scott Kraus \#1014. Woods Hole Oceanographic Institution Contribution \#10351. We thank Tim Stanton and Dezhang Chu for acoustic advice and encouragement. We also thank an anonymous reviewer for comments on the manuscript.

\section{REFERENCES}

Bamber, J.C. and Hill, C.R. 1979. Ultrasonic attenuation and propagation speed in mammalian tissues as a function of temperature. Ultrasound Med. Biol. 5:149-57.

Best, P. and Underhill, L. 1998. Population size, growth rate and survival of southern right whales Eubalaena australis off South Africa, 1979-1996. Paper SC/M98/RW15 presented to the IWC Special Meeting of the Scientific Committee towards a Comprehensive Assessment of Right Whales Worldwide, 16-25 March, Cape Town, South Africa. [Available from the Office of this Journal].

Best, P. B., Brandão, A. and Butterworth, D. 2001. Demographic parameters of southern right whales off South Africa. J. Cetacean Res. Manage (special issue) 2: 161-169.

Brown, M.W., Kraus, S.D., Gaskin, D.E. and White, B.N. 1994. Sexual composition and analysis of reproductive females in the North Atlantic right whale, Eubalaena glacialis, population. Mar. Mammal Sci. 10(3):252-65.

Caswell, H., Fujiwara, M. and Brault, S. 1999. Declining survival probability threatens the North Atlantic right whale. Proc. Natl Acad. Sci. USA 96(6):3,308-13.

Folch, J., Lees, M. and Stanley, G.H. 1957. A simple method for the isolation and purification of total lipids from animal tissues. J. Biol. Chem. 226:297-509.

Frisch, R.E. 1984. Body fat, puberty and fertility. Biol. Rev. 59:161-88.

Gales, N. and Burton, H. 1987. Ultrasonic measurement of blubber thickness of the southern elephant seal, Mirounga leonina (Linn.). Aust. J. Zool. 35:207-17.

Gammell, P.M., Le Croisette, D.H. and Heyser, R. 1979. Temperature and frequency dependence of ultrasonic attenuation in selected tissues. Ultrasound Med. Biol. 5:269-77.

Gaskin, D.E. 1991. An update on the status of the right whale, Eubalaena glacialis, in Canada. Can. Field-Nat. 105(2):198-205.

International Whaling Commission. 2001. Report of the Workshop on Status and Trends of Western North Atlantic Right Whales. J. Cetacean Res. Manage. (special issue) 2:61-87.

Iverson, S.J. 1988. Composition, intake and gastric digestion of milk lipids in pinnipeds. Ph.D. Thesis, University of Maryland, College Park, Maryland. 198pp.

Knowlton, A.R., Kraus, S.D. and Kenney, R.D. 1994. Reproduction in North Atlantic right whales (Eubalaena glacialis). Can. J. Zool. 72(7):1,297-305.

Kraus, S., Hamilton, P., Kenney, R., Knowlton, A. and Slay, C. 2001. Reproductive parameters of the North Atlantic right whale. $J$. Cetacean Res. Manage (special issue) 2: 231-236.

Lockyer, C.H., McConnell, L.C. and Waters, T.D. 1985. Body condition in terms of anatomical and biochemical assessments of body fat in North Atlantic fin and sei whales. Can. J. Zool. 63:2,328-38.

Luna, L. 1968. Manual of Histologic Staining Methods of the Armed Forces Institute of Pathology. McGraw-Hill, New York. 258pp. 
Marshall, F. and Hammond, J. 1926. The Physiology of Animal Breeding, with Special Reference to the Problem of Fertility. MAFF, London.

Matthews, L.H. 1938. Notes on the southern right whale, Eubalaena australis. Discovery Rep. 17:169-82.

McClements, D.J. and Povey, M.J.W. 1992. Ultrasonic analysis of edible fats and oils. Ultrasonics 30:383-8.

McIntire, P. 1991. Non-destructive Testing Handbook. American Society of Non-destructive Testing, Columbus, OH. 915pp.

Omura, H., Ohsumi, S., Nemoto, R., Nasu, K. and Kasuya, T. 1969. Black right whales in the North Pacific. Sci. Rep. Whales Res. Inst. Tokyo 21:1-78.

Pabst, D.A. 1990. Axial muscles and connective tissues of the bottlenose dolphin. pp. 51-7. In: S. Leatherwood and R. Reeves (eds.) The Bottlenose Dolphin. Academic Press, San Diego, CA. 653pp.
Payne, R., Rowntree, V., Perkins, J.S., Cooke, J.G. and Lankester, K. 1990. Population size, trends and reproductive parameters of right whales (Eubalaena australis) off Peninsula Valdes, Argentina. Rep. int. Whal. Commn (special issue) 12:271-8.

Smith, S.J., Iverson, S.J. and Bowen, W.D. 1997. Fatty acid signatures and classification trees; new tools for investigating the foraging ecology of seals. Can. J. Fish. Aquat. Sci. 54:1,377-86.

Thomas, V.G. 1990. Control of reproduction in animals species with high and low body fat reserves. Prog. Reprod. biol. Med. 14:27-41.

Thompson, D.W. 1928. On whales landed at the Scottish whaling stations during the years 1908-1914 and 1920-1927. Fish. Board Scotl. Sci. Invest. 3:3-39.

Whitehead, H.P. and Payne, R. 1981. New techniques for assessing populations of right whales without killing them. FAO Fish. Ser. (5) Mammals in the Seas:189-209. 